\title{
LUCIAN BLAGA: METAFORIZAREA POETICII GÂNDIRISTE
}

\section{Adela-Diana Chindriș Universitatea de Vest din Timișoara}

Abstract: The aim of this paper is to show how traditionalist elements are shaped in Lucian Blaga's poetry. After presenting some theoretical aspects about the literaray magazine Gândirea, the one Blaga collaborated with, we will explain how religious and rural motifs get a metaphysical pattern, in comparison with the way they are used in the traditionalist poems.

Key-words: religious symbols, rural area, tradition, modernism, metaphysics.

\section{Argument}

Oscilația poetului Lucian Blaga între revista Contimporanul și publicaţia Gândirea a creat probleme în încadrarea sa într-un anumit curent literar. Opera blagiană este străbătută atât de elemente moderniste, cu precădere expresioniste, cât și de elemente tradiționaliste, gândiriste. Astfel, lucrarea de față se bazează pe identificarea și explicarea celor din urmă. Vom urmări punctele de convergență şi divergență între poetica de tip gândirist și lirica lui Blaga, luând în considerare atât creația lui, cât și colaborarea cu revista. Ceea ce ne interesează în acest studiu este să marcăm, pe de o parte, faptul că Blaga nu poate fi subsumat unei singure mișcări literare (o viziune reducționistă ar diminua valoric opera poetului). Pe de altă parte, multe ,încadrări” ale autorului i-au fost mai degrabă imputate, iar revista Gândirea nu face excepție: publicația a avut mai mult de câștigat de pe urma asocierii cu Blaga.

\section{Delimitări conceptuale şi relația lui Blaga cu Gândirea}

Pentru început, demersului nostru îi sunt necesare câteva repere istorice. Gândirea apare la Cluj, în anul 1921, sub egida lui Cezar Petrescu și I. D. Cucu. Menirea cu care debutează revista era aceea de a oferi tinerilor scriitori șansa de a-și promova operele. Chiar dacă este lipsită de un articolprogram, această revistă atrage mulți scriitori și menține, pentru început, un echilibru între tendinţele moderniste şi cele tradiţionaliste. Se produce astfel o anumită hibridizare a specificului poeziilor, lucru care îi displace lui Nichifor Crainic, care își dorește ca revista să aibă un temei mai bine fixat - în spațiul și subiectele autohtone, căci unul dintre reproșurile aduse de gândiriști se referă la „anarhia” care domina primele decenii ale secolului al XX-lea, prin prezența, spre exemplu, a tumultuoaselor mișcări avangardiste.

Revista se mută la București în 1922, urmând ca din 1926 aceasta să fie patronată de Nichifor Crainic. În ceea ce privește ideologia gândiristă, 
Nichifor Crainic este cel care scoate în evidență câteva din trăsăturile fundamentale ale acesteia în diferite articole publicate în revistă. Unul dintre acestea este Sensul tradiției, publicat în 1929. La acea vreme atât societatea, cât și cultura românească se aflau într-o perioadă marcată de divergențe din punct de vedere socio-cultural. Ideile din Occident pătrundeau în spațiul românesc, unele fiind asimilate, altele nu. Oamenii de cultură erau împărțiţi în mai multe categorii din punctul de vedere al receptării conceptelor occidentale: cei care încurajau această receptare, în ideea ca aceasta să fie una absolută, cei care doreau o pliere a noilor idei pe fondul autohton și cei care erau în căutarea unui specific național românesc, având valoare autonomă. Din ultima categorie face parte acest Nichifor Crainic. Conform acestuia, „O cultură proprie nu se poate dezvolta organic decât în aceste condiții ale pământului și ale duhului nostru. Occidentalizarea înseamnă negarea orientalismului nostru, nihilismul europenizat înseamnă negarea posibilităţilor noastre creatoare. Ceea ce înseamnă negarea principală a unei culturi românești; negația unui destin propriu românesc, și acceptarea unui destin de popor mort."1. Căutarea unui specific național îndreaptă ideologia gândiristă spre extremism, în sensul apelului exclusiv la „un puternic rezervor de spriritualism românesc", în contextul creării României Mari, negând orice privire către exterior. Radicalizarea mișcării se explica prin îmbrățisarea ortodoxismului, văzut ca generator al specificului românesc: gândirismul trebuie să prindă „ca într-o pânză de păianjen întreaga vieață spirituală a neamului”"3.

Scriitorii care publică în această revistă se împart în două categorii, clasificați de către însuși Lucian Blaga, autor ce va face parte din „,comitetul” de conducere a revistei. Așadar, „,ei de dreapta” sau „,ei care s-au menținut cu strictețe în ogașele dogmatice ale ortodoxiei creștine" (aici sunt încadrați: Nichifor Crainic, Vasile Voiculescu, Dumitru Stăniloae, Ion Pillat, Victor Papilian etc) și „,cei care și-au îngăduit, sub privirea uneori mustrătoare a directorului, o anume libertate creatoare față de motivele creștine, convertindule în mituri și viziuni inedite" ". Lucian Blaga este unul dintre cei care optează pentru o liberalizare și îndepărtare de spiritul ortodoxist. În ciuda acestei „devieri”, Nichifor Crainic privește cu mare admirație poezia blagiană, care valorizează miturile, credințele și eresurile poporului român, pentru că, precum în cazul celorlalţi scriitori, avem de-a face cu ,,aceeași tendință a inspirației și o aceeași tendință de a se desprinde din plasticul artei lor sensul unei noi și înalte spiritualități”,

\footnotetext{
${ }^{1}$ Nichifor Crainic, Sensul tradiției, în Gândirea, anul IX, nr. 1-2, 1929.

${ }^{2}$ Gh. Vrabie, Gândirismul. Istoric, doctrină, realizări, Editura Cugetarea, București, p. 18.

${ }^{3}$ Idem, Ibidem, p. 67.

${ }^{4}$ Lucian Blaga, Nichifor Crainic, în Gândirea, XX, nr. 6, iunie 1941, p. 281.

${ }^{5}$ Gh. Vrabie, op. cit., p. 87.
} 
Sincronizarea primelor volume ale lui Blaga $\mathrm{cu}$ expresionismul german susține, într-o anumită măsură, încadrarea sa în direcția modernistă. La asta se adaugă și libertatea prozodică (absența ritmului, versul alb, ingambamentul). Astfel, ne punem întrebarea: cum e posibil ca unele opere blagiene să prezinte nuanțe gândiriste?

Blaga nu face parte din categoria poeților moderniști care atacă tradiţia. El o asimilează şi o revitalizează prin formulele prozodice noi, promovând un modernism eclectic. Acesta se confruntă cu întrebările şi problemele existențiale tipice moderniștilor, dar își caută liniștea, pe care o găsește în natură, spațiul arhaic și lumea mitică a satului românesc, cufundată în misterul divin creator. În acest sens, putem spune că Blaga apelează la același ,instrumentar” poetic precum gândiriștii, însă îl metaforizează printr-o spiritualizare care presupune transformarea ruralului în „sat-idee”, fără o atitudine refractară față de modernitate, fără inflexiuni ortodoxiste.

\section{Deus otiosus, „paradisul în destrămare” și alte simboluri religioase}

Gândiriștii promovează poezia religioasă cu nuanțe ortodoxiste. Lucian Blaga s-a abătut de la această cale. El a preia motive și teme religioase, însă le metaforizează, le conferă un caracter mitic sau chiar luciferic, având la bază filosofia și viziunea proprie asupra lumii. Totodată, forța divină apare sub mai multe forme și accepții în textele sale. Pentru a demonstra acest lucru, vom recurge la câteva dintre poeziile publicate de Blaga chiar în Gândirea - pe care, prin urmare, revista le-a girat și le-a considerat potrivite pentru a ilustra „doctrina” gândiristă.

Opera blagiană confirmă faptul că autorul „nu caută un Dumnezeu prezent, pe care nu îl găsește, ci un Dumnezeu absent, pe care îl dorește în «voința de credință», dar nu are un Dumnezeu pentru ea, întărindu-i astfel sentimentul înstrăinării în propria lui condiție umană. Ceea ce în poezia lui a fost numit «criză religioasă», este de fapt o dramă a căutării absolutului «ascuns» într-o revelație disimulată $"$.

În istoria religiilor se afirmă existența lui deus otiosus, care după crearea lumii, se retrage în liniștea primordială. Mircea Eliade admite prezența acestei ipostaze în folclorul religios românesc, considerând-o capitală în acest domeniu. Conform credințelor autohtone, Dumnezeu părăsea cerul din când în când alături de Sfântul Petru pentru a-și vizita creația. Fondul profan al lumii pământene 1-a făcut să se îndepărteze de aceasta.

La rândul său, Lucian Blaga susține și introduce în operele sale acest fenomen, fiind ilustrat în mai multe texte, printre care se numără și Psalm (publicată în Gândirea), care face parte din volumul În marea trecere. Poezia sintetizează condiţia omului modern cuprins de un sentiment de singurătate și

\footnotetext{
${ }^{6}$ Eugen Todoran, Lucian Blaga. Mit. Poezie. Mit poetic, Ed. Grai și suflet - Cultura națională, București, 1997.
} 
disperare, fiind departe de autoritatea divină. Acesta îi reproșează divinităţii absența din viața individului: „O durere totdeauna mi-a fost singurătatea ta ascunsă”. Sentimentul de deșertăciune este amplificat: „şi fără să-mi fi fost vreodată aproape / te-am pierdut pentru totdeauna / în ţărână, în foc, în văzduh şi pe ape" . Versurile acestea sugerează omniprezența creatorului în lume, cele patru elemente primordiale înglobându-l. Cu toate acestea, omul modern îl percepe pe creator ca fiind pierdut, ascuns. Spre deosebire de acest Mare Anonim blagian, în poezia lui Nichifor Crainic se observă nevoia stringentă de o divinitate prezentă, dar aici eul subiectiv este mereu pătruns de fiorul divin, îi simte prezența.

Lucian Blaga preia elementele din „decorul” mitologiei biblice pentru a sugera declinul veacului. Acest lucru se vede în poezia Paradis în destrămare, care face parte din volumul Lauda somnului, dar a apărut iniţial în revista Gândirea. Simbolurile prezente capătă o conotaţie ezoterică. Conform legendei biblice, îngerul care păzește intrarea în paradis poartă în mână o spadă de foc, simbolizând adevărul absolut. În poezia blagiană aceasta e „fără de flăcări”, trimițând la ideea de deșertăciune. Elementele din lumea mitică, biblică sunt prezentate din prisma negativului, a anihilării oricărui sâmbure de adevăr. „Serafimii cu părul nins” însetaţi de adevăr, apa fântânilor care „refuză gălețile lor”, arhanghelii suferinzi, ,porumbelul sfântului duh”, care, „cu pliscul stinge cele din urmă lumini”, îngeri goi, păienjeni care umple ,apa vie” etc. - toți aceștia creează un tablou lipsit de seninătatea în care gândiriștii plasau elementele componente. „Geografia mitologică” a lui Blaga se află sub semnul degradării. Criticul literar Ion Pop susține următoarele: „,paradisul în destrămare" este e un univers «lepădat» [...] o lume în care comunicării cu Ființa i s-a substituit închiderea, opacitatea, obstacolul"»8.

În poezia blagiană este utilizat cu precădere simbolul. Prin utilizarea acestuia, Blaga intensifică misterele existențiale fără să le dea o explicație clară. Câteva dintre simbolurile folosite sunt cele din care fac parte animalele „sfinte”, având astfel o tentă religioasă, însă una îndreptată spre metafizic. Ion Pop explică prezența acestora în poezia blagiană ca fiind o înclinare a poetului român spre partea genuină a naturii. „Un fior metafizic, o chemare de dincolo de lucruri străbate însă mereu în această lume elementară: un apel ce nu provoacă o reală suferinţă, ci reprezintă mai curând fascinaţia unei şi mai depline integrări în marele cosmos" $"$.

Şarpele este unul dintre animalele care apar în lumea poetică a lui Blaga. Acesta este prezentat din punct de vedre al bivalenţei sale. Pe de-o parte, se menţine ideea promovată de tradiţia creştină, cum că şarpele este un animal malefic, după cum se poate observa în poezia Pax magna: „,cu ochii de

\footnotetext{
${ }^{7}$ Lucian Blaga, Poezii, Ed. Eminescu, București, 1988, p. 62.

${ }^{8}$ Ion Pop, Lucian Blaga - Universul liric, Ed. Cartea românească, București, 1981, p. 201.

${ }^{9}$ Idem, Ibidem, p. 181.
}

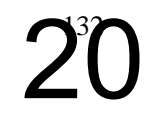


otravă $[\ldots]$ călcâiul adevărului să-l muşte-nveninându-l.” Pe de altă parte, pe fondul recăpătării armoniei dintre individ şi lumea exterioară, şarpele capătă conotaţii pozitive. Poezia Fiu al faptei nu sunt evidenţiază această ipostază: „dar încolăcit la picioarele mele / m-ascultă şi mă pricepe prea bine / şarpele cel cu ochii de-a pururi deschişi / spre înţelepciunea de dincolo." 10

Un alt animal frecvent întâlnit este balaurul. Utilizarea lui a determinat asocierea acestuia cu iconografia creştină: victimă a Sfântului Gheorghe, ca „duh al răului” - susţine Ion Pop, continuând- „el primeşte şi o puternică coloratură folclorică dezvăluind, alături de sensurile negative, şi un înţeles pozitiv." ". Imaginea balaurului trimite la „universul primar”, ${ }^{2}$, după cum spune Ion Pop. Poezia Sfântul Gheorghe bătrân (volumul Nebănuitele trepte) trimite la acest început al lumii, privit acum cu o mare nostalgie. Amintirea balaurului îi trezeşte cavalerului un sentiment de dor: „balaurul cu solzii-mprăştiaţi prin spini [...] din era prea fierbinte ce se sparse." ${ }^{\prime 13}$

Observăm că Lucian Blaga se foloseşte atât de elemente, cât şi de concepte din mitologia creştină. El însă nu le plasticizează aidoma gândiriştilor, ci trece spre un plan transcendent, oferindu-le un caracter metafizic. Bestiarul blagian pare similar orizonturilor creștine, însă chiar torsiunile primitive ale poeticii sale sunt asociate de gândiriști expresionismului. În mod curios și complet greșit, Gh. Vrabie alătură fondul folcloric şi primitivismul lui Blaga nevoii de religiozitate creștină a expresioniștior: „Întoarcerea către vechile tradiţii ale neamurilor, reluarea legăturilor cu superstițiile, datinile, viziunea apocaliptică, primitivismul, întrun cuvânt, din poezia lui Lucian Blaga este de natură expresionistă. Expresioniștii, care cred că arta trebuie să fie și religie, au reintrodus această notă esențială a poeziei cu gândul că numai în felul acesta se poate evada dintro lume a instinctelor și platitudinelor sociale, într-o alta, îmbibată de sfințenie și credincioșie" ${ }^{\prime 14}$. Dar la Blaga avem de-a face cu siguranță cu o reîntoarcere la o mitologie neoficializată, a „runelor”, locală, primitivă, necanonică şi necanonizată.

\section{Spaţiul rural şi întoarcerea la origini}

Dacă gândiriştii tratează satul şi, implicit, ţăranul într-un mod idilic, Blaga oferă o viziune mitică asupra spaţiului rural. Acesta vede satul ca fiind un punct de cotitură în viaţa omului. Este unicul loc în care acesta îşi poate găsi liniştea interioară. Conform gândirii blagiene, acesta este asociat veşniciei, aspect sugerat de poezia Sufletul satului (publicată tot la Gândirea),

\footnotetext{
${ }^{10}$ Lucian Blaga, Poezii, ed. cit., p. 78.

${ }^{11}$ Ion Pop, op. cit., p. 183.

${ }^{12}$ Idem, Ibidem, p. 184.

${ }^{13}$ Lucian Blaga, Poezii, ed. cit., p. 156

${ }^{14}$ Gh. Vrabie, op. cit., p. 231.
} 
apărută în volumul În marea trecere. Satul este văzut ca „centru al lumii”, acesta fiind un cronotop mitic: „Eu cred că veşnicia s-a născut la sat. / Aici orice gând e mai încet, / si inima-ţi zvâcneşte mai rar, / ca şi cum nu ţi-ar bate în piept, / ci adânc în pământ undeva." 15 . Aceste versuri trimit la ideea unei comuniuni între sufletul omului şi ţărâna din care provine. S-ar putea ca aceste versuri să trimită şi la dualitatea sat-oraş, dezbtută de către Blaga. Acesta afirmă în Elogiul satului românesc următoarele: „A trăi la oraş înseamnă a trăi în cadrul fragmentar şi în limitele impuse la fiecare pas de rânduieliele civilizaţiei. A trăi la sat înseamnă a trăi în zarişte cosmică şi în conştiinţa unui destin emanat din veşnicie.". Lucian Blaga vede satul ca fiind o eliberare, oferindu-i vitalitate: „Sufletul satului fâlfâie pe lângă noi, / ca un miros sfios de iarbă tăiată, ca o cădere de fum din streşini de paie, ca un joc de iezi pe morminte înalte" ${ }^{\prime 6}$. Poezia blagiana conţine o sinestezie aparte. Elemente ale vieţii rurale sunt metaforizate şi personificate pentru a trimite la o imagine plină de dinamism: mirosul „sfios” al ierbii proaspăt tăiate, jocul iezilor etc..

Un alt aspect interesant în poezia blagiană este raportarea sa la origini şi retrăirea trecutului. După cum ştim, gândiriştii sau mai bine zis, adepţii orientării tradiţionaliste în genere, şi-au manifestat interesul şi admiraţia faţă de continuarea tradiţiei, transmiterea ei, dar şi idealizarea trecutului (paseismul excesiv). Un astfel de exemplu este Ion Pillat. Alexandru Piru afirmă: „Departe de a fi descriptivă, exterioară, poezia lui Ion Pillat este o poezie interioară, de retrăiere a trecutului, actualizat cu infinita intensitate, în Pe Argeş in sus ${ }^{\text {"17 }}$. Ne interesează poezia intitulată Odaia bunicului, deoarece evocă un trecut îndepărtat, dar care nu poate fi uitat. Acesta rămâne impregnant în memoria eului, evocând atât sentimente de dor, cât şi de admiraţie: „Nu s-a clintit nimica şi recunosc iatacul / Bunicului pe care, viu, nu l-am cunoscut. / Rămase patu-i simplu şi azi nedesfăcut, /Şi ceasul lui pe masă, şi-a mai păstrat tictacul." ${ }^{\text {18 }}$. Insă la Pillat avem de-a face cu peisaje legate de zonele natale, cu o subiectivitate uneori melancolică, cu o figuralitate și plasticitate topice, convenționale, decorative, deloc spectaculoase.

Aparent, sunt comune câteva teme patriarhale la Pillat şi Blaga. Pentru Blaga satul reprezintă „locul mitologic unde, în cadrul existenţei ritualizate, omul singur poate reface comunicarea cu statornicul" ${ }^{\prime 19}$. Poezia Sat natal, dedicată lui Ion Pillat, pune în lumină două aspecte interesante. În primul rând, elementele cadrului natural al satului trimit la afirmaţia lui Pop privind întoarcerea la origini: „Nimeni nu mă cunoaşte. Vîntul, el singur, sau

\footnotetext{
${ }^{15}$ Lucian Blaga, Elogiul satului românesc, Academia română, Discursuri de recepțiune, 1937, reprodus în Izvoade, Ed. Minerva, 1979, p. 33-34.

${ }^{16}$ Lucian Blaga, Poezii, ed. cit., p. 71.

${ }^{17}$ Al. Piru, Istoria literaturii române, Ed. Grai și suflet - cultura națională, București, 1994, p. 228.

${ }^{18}$ Ion Pillat, Opere (Poezii 1918 - 1927), Ed. Eminescu, București, 1985.

${ }^{19}$ Ion Pop, op. cit., p. 194.
}

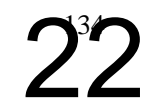


plopul / de aur. Plop înălţat / de-un fir nevăzut asemenea fusului. / Nedumirit turnul se va uita două ore în urma mea / pînă m-oi pierde din nou subt dunga apusului. " ${ }^{20}$. Natura este percepută ca element primordial, mereu îndreptat spre obârşie. În al doilea rând, se delimitează esenţa de materie. În poezia lui Ion Pillat amintită anterior, aspectul material juca un rol foarte important în rememorarea trecutului. La Blaga, însă, acest lucru nu e valabil: „Totul cît de schimbat! Casele toate sînt mult mai mici / decît le-a crescut amintirea."21. Expansiunea de sine este cea care aşază individualitatea în centrul poeticii blagiene, și nu descriptivismul paseist.

Deci, deducem că atât pentru Ion Pillat, un gândirist în adevăratul sens al cuvântului, cât şi pentru Lucian Blaga, spaţiul rural trimite la ideea de întoarcere la trecut, la strămoşi. Poetica blagiană însă conservă toate aceste idei într-o manieră revelatorie, lipsită de orice tentă bucolică, idilică.

\section{Concluzie}

Ajungând la finalul acestui studiu, trebuie să ofer o concluzie. O reflecţie ce s-ar cere făcută este aceea care vizează răspunsul la întrebarea: Aparţine Lucian Blaga categoriei de scriitori gândirişti? Acesta jonglează în opera sa cu diferite concepte promovate de Gândirea (fiinţa creatoare, satul, tradiţia), dar nu le atribuie aceleaşi valori. Acestea sunt proiectate într-un plan metafizic, depăşind cadrul experienţei şi care se află în strânsă legătură cu filosofia poetului.

\section{Bibliografie}

Nichifor Crainic, Sensul tradiției, în Gândirea, anul IX, nr. 1-2, 1929.

Lucian Blaga, Nichifor Crainic, în Gândirea, XX, nr. 6, iunie 1941.

Eugen Todoran, Lucian Blaga. Mit. Poezie. Mit poetic, Editura Grai și suflet Cultura națională, București, 1997.

Lucian Blaga, Poezii, Ed. Eminescu, Bucuresti, 1988.

Ion Pop, Lucian Blaga - Universul liric, Ed. Cartea romanească, București, 1981.

Lucian Blaga, Poezii, Ed. Eminescu, Bucuresti, 1988.

Ion Pop, Lucian Blaga - Universul liric, Editura Cartea românească, București, 1981.

Lucian Blaga, Elogiul satului românesc, Academia română, Discursuri de recepțiune, 1937, reprodus în Izvoade, Editura Minerva, 1979.

Al. Piru, Istoria literaturii romane, Editura Grai și suflet - cultura națională, București, 1994.

Ion Pillat, Opere (Poezii 1918 - 1927), Editura Eminescu, București, 1985.

${ }^{20}$ Lucian Blaga, Poezii, ed. cit., p. 104.

${ }^{21}$ Idem, Ibidem, p. 104. 